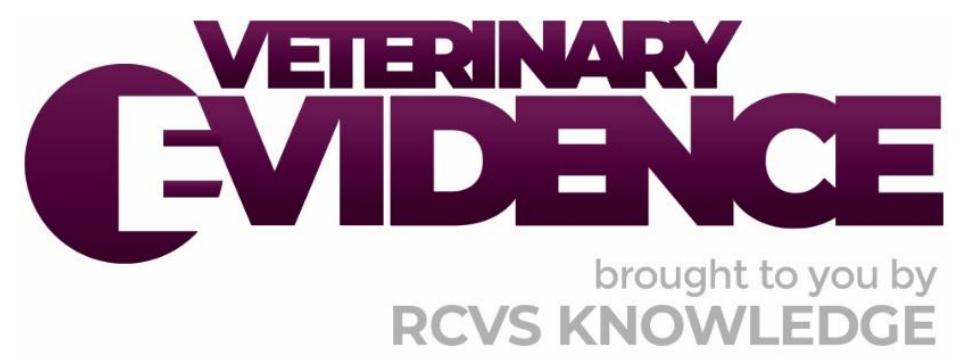

\title{
In Dogs Does Feeding Raw Dietary Treats Reduce or Prevent Periodontal Disease?
}

\section{A Knowledge Summary by}

Nieky van Veggel MSc, CBiol, FHEA ${ }^{1^{*}}$ James Oxley MRes ${ }^{2}$

\footnotetext{
${ }^{1}$ Writtle University College, Lordship Road, Chelmsford, Essex, CM1 3RR

2 Independent researcher, 102 Bosworth Road, Measham, Swadlincote, DE12 7LQ

*Corresponding Author (nieky.vanveggel@writtle.ac.uk)
}

ISSN: 2396-9776

Published: 17 Aug 2018

in: Vol 3, Issue 3

DOI: http://dx.doi.org/10.18849/ve.v3i3.153

Reviewed by: Simone Kirby (MRCVS, Dipl.EVDC) and Louise Buckley (BSc (Hons), BA (Hons), PG Cert (TLHEP), PGDip, PhD, RVN) and Kit Sturgess (MA, VetMB, PhD, CertVR, DSAM, CertVC, MRCVS) 


\section{KNOWLEDGE SUMMARY}

\section{PICO question}

In Dogs Does Feeding Raw Dietary Treats Reduce or Prevent Periodontal Disease?

\section{Clinical bottom line}

Considering the weak evidence on raw bones and lack of evidence on other types of raw treats, veterinarians and veterinary nurses should be cautious when recommending raw treats to support periodontal health in dogs. Additionally, they should advise clients accordingly by relying on their clinical experience rather than the literature until more and better quality evidence is generated.

\section{Clinical Scenario}

You are asked by a client for advice on improving the dental health of their dog after they read on the internet that periodontal disease negatively affects their dog's wellbeing. They read that feeding raw treats helps improve the dental health of their dog and are now asking you if there is evidence to support this.

\section{The evidence}

The research question effectively contains sub-questions addressing four topics: (1) preventive effects of raw treats vs. non-raw treats, (2) curative effects of raw treats vs. non-raw treats, (3) preventive effects of raw treats vs. no treats, and (4) curative effects of raw treats vs. no treats. There is currently no evidence directly comparing curative or preventive effects of raw dietary treats to non-raw treats (sub-questions 1 and 2 ) or for preventive effects of raw dietary treats compared to no treats at all (sub-question 3). Evidence for subquestion 4 was found in a paper by Marx et al. (2016), who described the use of two different raw bovine bone treats to reduce dental calculus. However, as this paper is a quasi-experimental non-randomised within-group comparison over time containing confounding variables, the risk of bias is judged as serious using the ROBINS-I tool (Sterne et al., 2016). Furthermore, the reporting of this paper did not adhere to guidelines for reporting non-randomised studies (Reeves and Gaus, 2004), which made a full critical appraisal difficult.

\section{Summary of the evidence}

\begin{tabular}{|c|c|}
\hline Population: & $\begin{array}{l}\text { Experiment 1: Healthy adult ( } 3 \pm 0.5 \text { years) laboratory housed Beagle } \\
\text { dogs who had never undergone dental cleaning and had never } \\
\text { received regular dental prophylaxis. } \\
\text { Experiment 2: The same group of laboratory housed Beagle dogs, } 7 \\
\text { months after experiment } 1 \text { finished. No dental prophylaxis was } \\
\text { administered in-between experiments. }\end{array}$ \\
\hline Sample size: & One group of 8 ( 4 male, 4 female) \\
\hline Intervention details: & $\begin{array}{l}\text { At the start of the study (day } 0 \text { ) dental calculus assessment was } \\
\text { conducted and compared to experiments } 1 \& 2 \text {. Dogs in each study }\end{array}$ \\
\hline
\end{tabular}




\begin{tabular}{|c|c|}
\hline & $\begin{array}{l}\text { were provided with a bone for } 12 \text { and } 20 \text { days respectively. } \\
\text { Experiment } 1 \text { : One piece of cortical bone (incl. marrow, raw bovine } \\
\text { femur, approx. } 4 \mathrm{~cm} \text { long, weighing } 122 \pm 17 \mathrm{~g} \text { ) daily for a period of } \\
12 \text { days. } \\
\text { Experiment 2: Seven months after experiment } 1 \text {, one piece of } \\
\text { epiphyseal bone (incl. marrow, raw bovine femoral epiphysis, } \\
\text { approx. } 5 \mathrm{~cm} \text { long, weighing } 235 \pm 27 \mathrm{~g} \text { ) was given to dogs daily for a } \\
\text { period of } 20 \text { days. } \\
\text { In both studies, the previous days bone was removed before } \\
\text { administering a new bone. Bones were obtained from a commercial } \\
\text { slaughterhouse, cut using a band saw then stored at - } 18^{\circ} \mathrm{C} \text { and } \\
\text { thawed before use. } \\
\text { Throughout both experiments dogs were kept in individual cages and } \\
\text { fed twice daily with a non-dental dry extruded complete commercial } \\
\text { diet that met approximate daily maintenance energy requirements. } \\
\text { Water was provided ad libitum. }\end{array}$ \\
\hline Study design: & $\begin{array}{l}\text { Both experiments: Quasi-experimental non-randomised within- } \\
\text { group baseline-to-intervention comparison over time. }\end{array}$ \\
\hline Outcome studied: & $\begin{array}{l}\text { Outcome } 1 \text {. Experiment } 1 \text { : Reduction (\%) of tooth area covered with } \\
\text { dental calculus over time }(1,3,7,9,12 \text { days) compared to baseline } \\
\text { day } 0 . \\
\text { Outcome 2, Experiment 2: Reduction (\%) of tooth area covered with } \\
\text { dental calculus over time }(1,3,7,9,12,14,17,20 \text { days) compared to } \\
\text { baseline day } 0 . \\
\text { Both experiments: Discrete measurements made on lateral view } \\
\text { photographs of the canines, premolars } 1-4 \text { and molars } 1-2 \text { of all } \\
\text { arcades using Image-Pro Plus image analysis software. } \\
\text { Outcome } 3 \text {. Comparison of calculus reduction between the two } \\
\text { experiments were compared over the twelve day period. }\end{array}$ \\
\hline $\begin{array}{l}\text { Main findings: } \\
\text { (relevant to PICO question): }\end{array}$ & $\begin{array}{l}\text { Outcome } 1 \text {. Experiment } 1 \text { : At day } 0 \text { mean dental calculus coverage } \\
\text { was } 42 \% \text { of total surface of dental arcade. After } 12 \text { days a } 70.6 \% \\
\text { reduction was observed to } 12.3 \% \text { of surface area }(P<0.05) \text {. } \\
\text { Outcome } 2 \text {. Experiment 2: At day } 0 \text { mean dental calculus coverage } \\
\text { was } 38.6 \% \text { of total surface of dental arcade. After } 12 \text { days an } 81.6 \% \\
\text { reduction was observed to } 7.1 \%(P<0.05) \text { and after } 20 \text { days an } 84 \% \\
\text { reduction to } 4.7 \% \text {. } \\
\text { Outcome } 3 \text {. No difference }(P=0.09 \text { ) was found when comparing } \\
\text { dental calculus reduction at day } 12 \text { during experiment } 1 \text { and day } 12\end{array}$ \\
\hline
\end{tabular}




\begin{tabular}{|c|c|}
\hline & $\begin{array}{l}\text { of experiment } 2 \text {. But a significant }(p<0.05) \text { reduction after day } 3 \text { was } \\
\text { seen and was lower in experiment } 1 \text { than in experiment } 2(35.5 \% \\
\text { and } 56.5 \% \text { respectively). }\end{array}$ \\
\hline Limitations: & $\begin{array}{l}\text { This paper describes a non-randomised study with within } \\
\text { group comparisons over time. A reason for not using a } \\
\text { randomised between-group comparison design was not } \\
\text { provided, even though it appears a more straightforward } \\
\text { option. } \\
\text { The comparison between the two treatments is confounded } \\
\text { by the fact that for cortical bone, dogs had received no } \\
\text { dental prophylaxis for three years, whereas for epiphyseal } \\
\text { bone they received no prophylactic treatment for } 7 \text { months. } \\
\text { Having said this, it is important to highlight the similarities } \\
\text { between the calculus build up on the first days in the first } \\
\text { (42\% calculus coverage of dental arcades) and second study } \\
\text { (38.6\% calculus coverage of dental arcades). This could } \\
\text { explain the reduced calculus coverage at the start of } \\
\text { experiment } 2 \text { and/or the limited long term effect of } \\
\text { prophylactic treatment over a } 7 \text { month period. } \\
\text { The sample size is very small, with a narrow age range. The } \\
\text { reason for this is not provided. } \\
\text { The dogs used in this study are unlikely to be representative } \\
\text { of pet dogs, which makes extrapolating findings } \\
\text { troublesome. } \\
\text { Data in the results section did not show exact data from all } \\
\text { days of experiments. Mean reduction was only shown in a } \\
\text { percentage without including indicators variance. Only the p } \\
\text { value was provided for statistics. } \\
\text { Extrapolations regarding efficacy compared results to other } \\
\text { calculus reducing methods were made using the literature, } \\
\text { even though no direct comparisons have been performed. } \\
\text { This paper does not adhere to guidelines for reporting non- } \\
\text { randomised studies (Reeves and Gaus, 2004). For example, it } \\
\text { does not explain why an RCT was not possible or reports on } \\
\text { precautions to reduce bias, nor does it provide information } \\
\text { on other environmental enrichment provided to the dogs } \\
\text { under investigation. }\end{array}$ \\
\hline
\end{tabular}

\section{Appraisal, application and reflection}

Raw feeding has become an increasingly popular concept in companion animals in recent years (Schlesinger and Joffe, 2011; Freeman et al., 2013; Fredriksson-Ahomaa et al., 2017). Recent research (Morgan et al., 2017) highlighted that owners searching for information on raw diets are more reliant on online resources due to a lack of trust in the veterinary profession regarding this topic. This indicates the importance of veterinary practitioners having access to high quality evidence on raw feeding to educate owners during consultations. However, the evidence-base for raw feeding-related issues in dogs, and companion animals in general, is lacking with the majority of evidence being of an anecdotal nature. Most research relating to raw feeding to date has focused on nutritional risk/benefit to the animal and public health and consumer safety (for example see Finley et al., 2006; Fredriksson-Ahomaa et al., 2017; van Bree et al., 2018). Schlesinger and Joffe (2011) 
argue that although some high-level evidence based on mainly North American studies is available regarding the latter, the evidence base for the former is weak. Recent work by van Veggel and Armstrong (2017) found no evidence regarding effects of feeding raw complete diets on dental health in dogs. In the current study on raw complementary feeds, this lack of evidence is similar, with no evidence available for effects on dental health of any type of dietary raw treat other than raw bones. However, the evidence on raw bones (Marx et al., 2016) is weak due to a serious risk of bias caused by limitations in the experimental design. Furthermore, weaknesses in reporting meant this research was difficult to fully appraise.

This Knowledge Summary specifically excluded research on rawhides and rawhide products. Due to the industrial techniques used to manufacture these products, the authors do not consider them to be a raw feed in the true nature of the word. The evidence of potential effects of rawhide products on dental hygiene in dogs would merit appraisal in a separate Knowledge Summary.

In all literature search strategies, the balance between sensitivity and precision of the literature search is key (O'Connor et al., 2014). Due to the nature of the evidence regarding raw feeding, similar to work by van Veggel and Armstrong (2017) and Taylor and van Veggel (2018), the search strategy for this paper was deliberately on the sensitive side so that no potential relevant papers would be missed. As a result, the authors believe the outcome of this paper to be representative of the lack of research on raw feeds and feeding, rather than it being related to the specificity of the literature search strategy. This Knowledge Summary clearly highlights a gap in the evidence, therefore a strong justification (Lund et al., 2016) for further research is present. The authors therefore recommend original research in the form of a randomised controlled study into dental health and complementary raw feeding is undertaken while keeping risks to humans caused by feed hygiene issues (van Bree et al). (2018) in mind.

\title{
Methodology Section
}

\begin{tabular}{|c|c|}
\hline \multicolumn{2}{|l|}{ Search Strategy } \\
\hline $\begin{array}{r}\text { Databases searched and dates } \\
\text { covered: }\end{array}$ & $\begin{array}{l}\text { CAB Abstracts (1973 - June 2017) } \\
\text { PubMed (1950 - June 2017) - Veterinary Science filter applied }\end{array}$ \\
\hline Search terms: & $\begin{array}{l}\text { (dog OR dogs OR canine OR canines OR bitch OR bitches) AND } \\
\text { ('periodontal disease' OR gingivitis OR gingiva OR tartar OR plaque } \\
\text { OR stomatitis OR periodontitis OR 'gum disease' OR 'dental disease' } \\
\text { OR calculus) AND (feed OR diet OR food OR 'pet food' OR 'dental } \\
\text { treats' OR treats OR snack OR chew OR bone OR knuckle OR hide OR } \\
\text { biscuit OR titbits) }\end{array}$ \\
\hline Dates searches performed: & 19 June 2017 \\
\hline
\end{tabular}

\section{Exclusion / Inclusion Criteria}

Inclusion and exclusion criteria were determined in advance of the search phase. Papers were screened by both authors independently by title and abstract and included for analysis if they met the inclusion criteria below. Where there was doubt, papers were included. Subsequently, full-text articles were obtained and a second inclusion/exclusion phase based on the criteria below was performed. Where there was doubt about the suitability of a full text paper, an independent party was consulted and a majority vote applied.

\author{
Exclusion: Not related to PICO \\ Not addressing raw complementary feed \\ Review papers \\ Non-peer reviewed material
}


Inclusion: Primary research papers OR

Systematic reviews (SR) AND

Dental hygiene using any types of complementary raw feeds

\begin{tabular}{|l|c|c|c|c|c|c|}
\hline \multicolumn{2}{|l|}{ Search Outcome } \\
\hline Database & $\begin{array}{r}\text { Number } \\
\text { of } \\
\text { results }\end{array}$ & $\begin{array}{c}\text { Excluded - } \\
\text { not related } \\
\text { to PICO }\end{array}$ & $\begin{array}{c}\text { Excluded - Not } \\
\text { peer reviewed }\end{array}$ & $\begin{array}{c}\text { Excluded - not } \\
\text { primary } \\
\text { research }\end{array}$ & $\begin{array}{c}\text { Excluded - not } \\
\text { raw treat }\end{array}$ & $\begin{array}{c}\text { Total } \\
\text { relevant } \\
\text { papers }\end{array}$ \\
\hline $\begin{array}{l}\text { CAB } \\
\text { Abstracts }\end{array}$ & 368 & 338 & 5 & 9 & 15 & 1 \\
\hline PubMed & 1368 & 1351 & 3 & 5 & 8 & 1 \\
\hline \multicolumn{2}{l|}{ Total relevant papers when duplicates removed } & & & 1 \\
\hline
\end{tabular}

\section{CONFLICT OF INTEREST}

Nieky van Veggel is a member of the editorial board of Veterinary Evidence.

This paper underwent a rigorous peer-review process as per our normal reviewing guidelines of inviting a minimum of two external reviewers. The identity of the Associate Editor handling the paper has not been disclosed to the author. The final decision to accept this paper rested with the Editor-in-chief.

The authors would like to gratefully acknowledge Clare Boulton (RCVS Knowledge) for her help with finalising the search strategy and retrieving full-text papers.

\section{REFERENCES}

1. Bond, J. C. and Lindburg, D. G. (1990) Carcass Feeding of Captive Cheetahs (Acinonyx Jubatus): The Effects of a Naturalistic Feeding Program on Oral Health and Psychological Well-Being. Applied Animal Behaviour Science, 26 (4), pp. 373-382. DOI: http://dx.doi.org/10.1016/0168-1591(90)90036-D

2. Fagan, D. A. (1980) Diet Consistency and Periodontal Disease in Exotic Carnivores. In: Proceedings of the American Association of Zoo Veterinarians, pp. 34-37. Available

at http://citeseerx.ist.psu.edu/viewdoc/summary?doi=10.1.1.462.6411

3. Fredriksson-Ahomaa, M., Heikkilä, T., Pernu, N., Kovanen, S., Hielm-Björkman, A., Kivistö, R. (2017) Raw Meat-Based Diets in Dogs and Cats. Veterinary Sciences. 4(3), 33.

DOI: http://dx.doi.org/10.3390/vetsci4030033

4. Finley, R., Reid-Smith, R., Weese, J.S. and Angulo, F.J. (2006) Human health implications of Salmonellacontaminated natural pet treats and raw pet food. Clinical Infectious Diseases, 42 (5), pp. 686-691. 
DOI: http://dx.doi.org/10.1086/500211

5. Freeman, L. M., Chandler, M. L., Hamper, B. A., et al. (2013) Current Knowledge about the Risks and Benefits of Raw Meat-Based Diets for Dogs and Cats. Journal of the American Veterinary Medical Association, 243 (11), pp. 1549-1558. DOI: https://doi.org/10.2460/javma.243.11.1549

6. Lund, H. Brunnhuber, K. Juhl, C. et al. (2016) Towards Evidence Based Research. British Medical Journal, 355, October, i5440. DOI: http://dx.doi.org/10.1136/bmj.i5440

7. Marx, F.R., Machado, G.S., Pezzali, J.G., Marcolla, C.S., Kessler, A.M., Ahlstrom, O., Trevizan, L. (2016) Raw beef bones as chewing items to reduce dental calculus in Beagle dogs. Australian Veterinary Journal, 94 (1-2), pp. 18-23. DOI: http://dx.doi.org/10.1111/avj.12394

8. Morgan, S.K., Willis, S., Shepherd, M.L. (2017) Survey of owner motivations and veterinary input of owners feeding diets containing raw animal products. PeerJ. 5, e3031.

DOI: http://dx.doi.org/10.7717/peerj.3031

9. O'Connor, A. M. Anderson, K. M. Goodell, C. K. et al. (2014) Conducting Systematic Reviews of Intervention Questions I: Writing the Review Protocol, Formulating the Question and Searching the Literature. Zoonoses and Public Health, 61, 28-38. DOI: https://doi.org/10.1111/zph.12125

10. Reeves, B.C., Gaus, W. (2004) Guidelines for reporting non-randomised studies. Complementary Medicine Research. 11 Suppl 1, pp. 46-52. DOI: http://dx.doi.org/10.1159/000080576

11. Schlesinger, D. P. and Joffe, D. J. (2011) Raw food diets in companion animals: a critical review. The Canadian Veterinary Journal, 52 (1), pp. 50-54. Available at https://www.ncbi.nlm.nih.gov/pmc/articles/PMC3003575/

12. Sterne, J.A., Hernán, M.A., Reeves, B.C., Savović, J., Berkman, N.D., Viswanathan, M., Henry, D., Altman, D.G., Ansari, M.T., Boutron, I., Carpenter, J.R., Chan, A.-W., Churchill, R., Deeks, J.J., Hróbjartsson, A., Kirkham, J., Jüni, P., Loke, Y.K., Pigott, T.D., Ramsay, C.R., Regidor, D., Rothstein, H.R., Sandhu, L., Santaguida, P.L., Schünemann, H.J., Shea, B., Shrier, I., Tugwell, P., Turner, L., Valentine, J.C., Waddington, H., Waters, E., Wells, G.A., Whiting, P.F., Higgins, J.P. (2016) ROBINS-I: a tool for assessing risk of bias in non-randomised studies of interventions. British Medical Journal. 355, i4919. DOI: http://dx.doi.org/10.1136/bmi.i4919

13. Taylor, E. and van Veggel, N. (2018) In adult dogs, does feeding a raw food diet increase the risk of urinary calculi formation compared to feeding a complete dry kibble diet?. Veterinary Evidence. 3(2). DOI: http://dx.doi.org/10.18849/ve.v3i2.155

14. van Bree, F.P.J., Bokken, G.C.A.M., Mineur, R., Franssen, F., Opsteegh, M., van der Giessen, J.W.B. van der, Lipman, L.J.A., Overgaauw, P.A.M., 2018. Zoonotic bacteria and parasites found in raw meatbased diets for cats and dogs. Veterinary Record. DOI: http://dx.doi.org/10.1136/vr.104535

15. van Veggel, N. and Armstrong, M. (2017) In Dogs with Periodontal Disease Is Feeding a Complete Raw Meat Diet More Effective Than a Complete Kibble 'Dental' Diet at Reducing Periodontal Disease? Veterinary Evidence. 2(2). DOI: http://dx.doi.org/10.18849/ve.v2i2.88 


\section{EVIIDEFeE

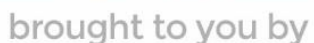 \\ RCVS KNOWLEDGE}

\section{Intellectual Property Rights}

Authors of Knowledge Summaries submitted to RCVS Knowledge for publication will retain copyright in their work, and will be required to grant RCVS Knowledge a non-exclusive license of the rights of copyright in the materials including but not limited to the right to publish, re-

publish, transmit, sell, distribute and otherwise use the materials in all languages and all media throughout the world, and to license or permit others to do so.

\section{Disclaimer}

Knowledge Summaries are a peer-reviewed article type which aims to answer a clinical question based on the best available current evidence. It does not override the responsibility

of the practitioner. Informed decisions should be made by considering such factors as individual clinical expertise and judgement along with patient's circumstances and owners' values. Knowledge Summaries are a resource to help inform and any opinions expressed within the Knowledge Summaries are the author's own and do not necessarily reflect the view of the RCVS Knowledge. Authors are responsible for the accuracy of the content. While the

Editor and Publisher believe that all content herein are in accord with current recommendations and practice at the time of publication, they accept no legal responsibility

for any errors or omissions, and make no warranty, express or implied, with respect to material contained within.

For further information please refer to our Terms of Use.

RCVS Knowledge is the independent charity associated with the Royal College of Veterinary Surgeons (RCVS). Our ambition is to become a global intermediary for evidence based veterinary knowledge by providing access to information

that is of immediate value to practicing veterinary professionals and directly contributes to evidence based clinical decision-making.

https://www.veterinaryevidence.org/

RCVS Knowledge is a registered Charity No. 230886.

Registered as a Company limited by guarantee in England and Wales No. 598443.

Registered Office: Belgravia House, 62-64 Horseferry Road, London SW1P 2AF

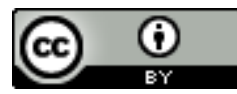

This work is licensed under a Creative Commons Attribution 4.0 International License 